\title{
Hyaluronic Acid-containing Topical Cream
}

National Cancer Institute

\section{Source}

National Cancer Institute. Hyaluronic Acid-containing Topical Cream. NCI Thesaurus.

Code C116712.

A topical cream formulation containing hyaluronic acid (HA) with wound repair promoting, skin moisturizing and potential radioprotective activities. Upon application of the topical cream, HA adheres to injured tissues, provides hydration to the skin, and protects against dehydration and chemical or mechanical irritation. Hyaluronate, a non-sulfated glucosaminoglycan, is a major component of the extracellular matrix in connective, epithelial, and neural tissues and contributes significantly to cell proliferation and migration. 